\title{
Investigation of biofilm formation of Enterococcus species isolated from blood by phenotypic and genotypic methods
}

\section{Kandan izole edilen Enterococcus türlerinde biyofilm olușumunun fenotipik ve genotipik yöntemlerle araștırılması}

\author{
Zeynep ÖZKÖK¹ (ID), Kemal BílGiN² (ID), Yeliz TANRIVERDi ÇAYCI ${ }^{2}$ (ID), Asuman BíRiNCi²
}

\section{ABSTRACT}

Objective: Enterococcus spp. are widely found in enviroment and can cause diseases. Although the factors that explain its virulence have not yet been fully clarified, enterococcal surface protein (esp) has been associated with the ability of biofilm formation in both Enterococcus faecalis and the Enterococcus faecium. In our study, it was aimed to determine the vancomycin resistance status of $E$. faecalis and $E$. faecium species and to investigate the presence of esp gene which is thought to be related of with polymerase chain reaction and biofilm formation capacity by phenotypic methods.

Methods: A total of 170 Enterococcus spp. (E. faecalis $\mathrm{n}=85, E$. faecium $\mathrm{n}=85$ ) isolates that were isolated from blood culture were included in the study. Species identification was performed using conventional and automated methods. Vancomycin susceptibilities of isolates were determined by Kirby-Bauer disk diffusion method. Biofilm formation was evaluated phenotypically by using Tube and Microtitration plate methods. In all isolates, the presence of esp gene which is associated biofilms was investigated by polymerase chain reaction (PCR) method.

\section{ÖZET}

Amaç: Doğada yaygın olarak bulunabilen enterokoklar, çeșitli enfeksiyonlara neden olabilmektedir. Virülansını açıklayan faktörler henüz tam olarak netlik kazanmamıs olmakla birlikte enterokokal yüzey proteini (esp), hem Enterococcus faecalis hem de Enterococcus faecium'un biyofilm olușturma yeteneğiyle ilișkilendirilmektedir. Çalıșmamızda $E$. faecalis ve $E$. faecium türlerinin vankomisine direnç durumlarının belirlenmesi ve biyofilm oluşumu ile ilișkili olduğu düșünülen esp gen varlığının polimeraz zincir reaksiyonu ile, biyofilm olușturma kapasitelerinin de fenotipik yöntemlerle araștırılması amaçlanmıștır.

Yöntem: Çalıșmaya kan kültüründen izole edilen 85'i E. faecalis, 85'i E. faecium olacak șekilde toplam 170 adet Enterococcus izolatı dahil edilmiștir. Türlerin tanımlanması konvansiyonel ve otomatize yöntemler kullanılarak yapılmıștır. İzolatların vankomisine duyarlılıkları Kirby-Bauer disk difüzyon yöntemiyle belirlenmiștir. Tüm izolatlar tüp ve mikrotitrasyon plak yöntemleri kullanılarak biyofilm olușumu yönünden fenotipik olarak değerlendirilmiștir. Ayrıca izolatlarda, Polimeraz Zincir Reaksiyonu (PZR) yöntemi kullanılarak enterokoklarda biyofilm olușumu ile ilișkili olduğu düșünülen esp geninin varlığı araștırılmıștır.

'Başakşehir Çam and Sakura City Hospital, İstanbul

${ }^{2}$ Ondokuz Mayıs University, Faculty of Medicine, Department of Medical Microbiology, Samsun

İletişim / Corresponding Author : Kemal BILLGiN

Ondokuz Mayıs Üniversitesi, Tip Fakültesi, Tibbi Mikrobiyoloji AD Samsun - Türkiye

E-posta / E-mail : kemal.bilgin@omu.edu.tr

Geliş Tarihi / Received : 17.03.2020

Kabul Tarihi/Accepted : 29.06 .2021

DOI ID : 10.5505/TurkHijyen.2021.02328

Özkök Z, Bilgin K, Tanrıverdi Çaycı Y, Birinci A. Investigation of biofilm formation of Enterococcus species isolated from blood by phenotypic and genotypic methods. Turk Hij Den Biyol Derg, 2021; 78(3): 363 - 372 
Results: When the vancomycin susceptibilities of the strains included in the study were examined, it was found that 14 of the $E$. faecalis isolates (16.5\%) were moderately susceptible and 1 of them was (1.2\%) resistant. And 29 (34.1\%) of $E$. faecium isolates were found to be resistant. It was determined that 5 strains (5.9\%) were formed biofilm by tube method. By microtiter plate method, 27 (31.8\%) tested strains were determined positive for biofilm formation. The 5 isolates which were positive by tube method also found positive by microtiter plate method. All strains that were positive in both phenotypic methods were found to be $E$. faecalis. And 49 (57.6\%) $E$. faecalis and $20(23.5 \%)$ E. faecium strains were found positive esp. When the genotypic method was compared with phenotypic methods, 24 isolates which were found positive by microtiter plate method and 5 isolates which were found positive by tube method, were found positive for esp gene.

Conclusion: According to these results, E. faecalis isolates are thought to have higher biofilm formation capacity than E. faecium. Furthermore, it is thought that the esp gene may be related to biofilm formation but the presence of esp alone is not sufficient for biofilm formation. New and comprehensive studies on the subject will be able to provide new and useful data on the role of biofilm formation in the virulence of enterococci.

Key Words: Enterococcus spp., biofilm, virulence factors
Bulgular: Çalıșmaya dahil edilen sușların vankomisine duyarlılıkları incelendiğinde, $E$. faecalis izolatlarının 14 tanesi $(\% 16,5)$ orta duyarlı, 1 tanesi $(\% 1,2)$ dirençli; E. faecium izolatlarının ise 29 tanesi $(\% 34,1)$ dirençli olarak bulunmuștur. Tüp yöntemi ile 5 suşun $(\% 5,9)$ biyofilm olușturduğu görülmüștür. Mikrotitrasyon plak yöntemi ile ise 27 suş $(\% 31,8)$ pozitif olarak tespit edilmiștir. Tüp yönteminde pozitif çıkan beș izolatın hepsinin aynı zamanda mikrotitrasyon yönteminde de pozitif olduğu görülmüștür. Her iki fenotipik yöntemde de pozitif olan sușların tamamının $E$. faecalis olduğu görülmüștür. PZR ișleminin sonucunda $49(\% 57,6) E$. faecalis, $20(\% 23,5)$ E. faecium sușunda esp varlığı saptanmıștır. Fenotipik yöntemler ile genotipik yöntem karșılaștırıldığında mikrotitrasyon plak yönteminde pozitif olan izolatlardan 24 tanesi, tüp yönteminde pozitif olan izolatlardan ise 5 tanesinde esp geninin varlığı tespit edilmiștir.

Sonuç: Bu bulgulara göre E. faecalis izolatlarının biyofilm oluşumu kapasiteleri $E$. faecium'a göre daha fazla bulunmuștur. Ayrıca esp geninin biyofilm olușumu ile ilgisi olabileceği ancak tek bașına esp varlığının biyofilm oluşumu için yeterli olamayacağı düşünülmektedir. Konu ile ilgili yapılacak yeni ve kapsamlı çalışmalar enterokoklarda biyofilm olușumunun virülansdaki rolü ile ilgili yeni ve faydalı veriler sağlayabilecektir.

Anahtar Kelimeler: Enterococcus spp., biyofilm, virülans faktörü

\section{INTRODUCTION}

Although there are 18 different strains in the genus Enterococcus, the most common infection in humans Enterococcus faecalis (responsible for $80-90 \%$ of all enterococcal infections) and Enterococcus faecium (tends to be more resistant to antibiotics) (1).
Enterococci cause a variety of infections, including meningitis, respiratory system infections, endocarditis, intra-abdominal and pelvic infections, urinary tract infections, bacteremia, wound, and tissue infections and neonatal sepsis (2). 
Virulence factor of enterococci has not yet been fully clarified $(3,4)$. However, they are considered to be pathogenicity factors such as enterococcal surface protein (esp), aggregation factor, lipoteichoic acid, bacteriocin, gelatinase, serine protease and hyaluronidase (5). In these factors, there are publications that esp associated with the ability of both $E$. faecalis as well as $E$. faecium to form biofilm (6). Biofilm can be defined as the placement of the microorganism within a matrix of extracellular polymeric material that irreversibly binds to a surface, interface or to each other (7).

Virulence factors situated in the strains of $E$. faecalis and $E$. faecium may play a role in colonizing and initiating infection by forming biofilm (6). Biofilm formation has been investigated in strains isolated from different samples in various studies, but not all of the studies have blood isolates $(7,8)$. Knowledge of their own patient profile, microorganisms that make up the hospital flora, and their resistance patterns will enable health institutions to develop the right strategies (9).

In this study, it was aimed to determine the vancomycin resistance status of $E$. faecalis and $E$. faecium species and to investigate the presence of esp gene which is thought to be related of with polymerase chain reaction and biofilm formation capacity by phenotypic methods.

\section{MATERIAL and METHOD}

Isolates

A total of $170 E$. faecium and E. faecalis clinical isolates, recovered from blood culture samples, sent from various services between June 2016 - June 2017, were included. Only one sample of for patient included in the study. Non-biofilm former Escherichia coli ATCC 25922, and biofilm former Acinetobacter baumanii ATCC 19606 was used as control strains.

Identification of the isolates included in the study was performed using conventional methods and Vitek-
MS (bioMérieux, France) system.

\section{Determination of antimicrobial resistance}

The vancomycin resistance of the isolates used in the study was first determined by the Vitek 2 Compact (bioMérieux, France) system and then the Kirby-Bauer disk diffusion method was performed according to CLSI recommendations and interpreted (10).

\section{Investigation of biofilm presence}

In order to investigate the presence of biofilm in enterococci phenotypically tube method and microtitration plate management were performed.

Tube method

Tryptic Soy Broth (TSB) (BD, France) containing $0.25 \%$ glucose was prepared sterile for tube biofilm research. The prepared medium was dispensed into $5 \mathrm{ml}$ of pre-sterilized glass tubes. A few colonies were then taken from freshly produced isolates in blood agar (Himedia, India) and inoculated into tubes containing $5 \mathrm{ml}$ of TSB.

The tubes were incubated at $35^{\circ} \mathrm{C}$ for 48 hours. At the end of the period, the whole surface of the glass tubes was aspirated without contacting the pipette. $1 \mathrm{ml}$ of $25 \%$ safranine (Merck, Germany) was added into the evacuated tube and the tube was capped to stain the inner surface and gently turned. After the entire surface had come into contact with the paint, it was checked whether a film had formed on the inner surface of the tube and evaluated as follows: it was scored negative if there was no staining on the wall; it was scored +1 if there is very slight staining on the side of the tube; it was scored +2 if there is slight staining on the side of the tube; it was scored +3 if there was intense staining along the walls of the tube. As a result of this grading, negative and +1 results were evaluated as negative, +2 and +3 results were evaluated as positive for tube method. In addition, the formation of an annular strip only on the air contacting part of the medium was also considered a negative result (11). 


\section{Microtitration plate method}

Enterococcus isolates were passaged into the blood agar medium in a pure manner. Passaged enterococci were seeded on TSB medium containing $0.25 \%$ glucose and incubated for 24 hours at $36^{\circ} \mathrm{C}$. After incubation, cultures were diluted 1:20; 200 $\mu \mathrm{l}$ of each well was placed in a 96-well flat-bottom polystyrene microtitration plate. Thus, the plate was allowed to incubate at $36^{\circ} \mathrm{C}$ for 24 hours. After incubation, the medium in the wells was aspirated. After, it was gently washed three times with sterile distilled water and inverted and dried. $100 \mu \mathrm{l}$ of a $1 \%$ crystal violet (Merck, China) solution prepared into the wells were dispersed and incubated at room temperature for 15 minutes. After staining, the plate was washed 3 times with sterile distilled water and inverted and dried. $200 \mu \mathrm{l}$ of the ethanol/acetone $(80: 20)$ solution, prepared to dissolve the stain, was dispensed and the stain was allowed to dissolve for 10 minutes. Plates were then read in ELISA (ChroMate, USA) reader at $492 \mathrm{~nm}$ wavelength $(12,13)$.

Each isolate was studied 3 times by microtitration plate method. The results were evaluated according to the optical density values of the positive and negative control strains $(13,14)$.

\section{DNA extraction from isolates}

DNA extraction of Enterococcus isolates was performed by boiling (15). The resulting DNAs were stored at $-20{ }^{\circ} \mathrm{C}$ until use.

Analysis of esp gene with PCR analysis

The presence of esp gene was investigated by PCR.
For this purpose, primers esp11 and esp12, which multiply the region of $954 \mathrm{bp}$ were used (16). The base sequences of the primers are given in Table 1.

PCR reaction content was prepared according to the amounts defined by Shankar et al (16). The amplification program, identified by Shankar et al (16), was modified and used. Amplification was carried out with the following thermal cycling profile: 2 min at $95^{\circ} \mathrm{C}$ and 30 cycles of amplification consisting of 45 sec at $94^{\circ} \mathrm{C}, 45 \mathrm{sec}$ at $54^{\circ} \mathrm{C}$ and $4 \mathrm{~min}$ at $72^{\circ} \mathrm{C}$ and 5 $\min$ at $72^{\circ} \mathrm{C}$ for the final extension.

The amplificated products were subjected to electrophoresis for 1 hour at $120 \mathrm{~V}$ on $1.5 \%$ agarose gel (Biomax). At the end of the procedure, the gels were kept in distilled water containing $0.5 \mu \mathrm{g} /$ $\mathrm{ml}$ ethidium bromide for 20 minutes. At the end of the period, gels were examined for the presence of bands under UV light (Biorad, Italy) and the image was recorded and stored.

In order to confirm the duplicated region, the product selected as an example from amplicon shown to be positive in electrophoresis, sequence process applied (Sentebiolab, Turkey).

\section{Statistical analysis}

The data were analyzed using IBM SPSS V23. Pearson chi-square test was used to compare the method results according to the species. Significance level was considered as $p<0.05$.

This study was carried out with the permission of 2017/321 granted by Ondokuz Mayıs University Clinical Research Ethics Committee on 14.09.2017.

Table 1. Sequences of esp11 and esp12 primers

\begin{tabular}{|c|r|r|}
\hline Primary & Primary Sequences $\left(5^{\prime}-3^{\prime}\right)$ & Size (bp) \\
\cline { 1 - 2 } esp11 & TTGCTAATGCTAGTCCACGACC & 954 \\
\hline esp12 & GCGTCAACACTTGCATTGCCGAA & \\
\hline
\end{tabular}




\section{RESULTS}

\section{Resistance to vancomycin}

When the susceptibility of 85 isolates of $E$. faecalis to vancomycin was evaluated; $70(82.3 \%)$ were susceptible, 14 (16.5\%) were moderately susceptible and one (1.2\%) resistant. It was seen that $56(65.9 \%)$ of 85 isolates were susceptible and 29 (34.1\%) were resistant in $E$. faecium.

Four $(80 \%)$ of the five isolates that were positive by tube method were found to be susceptible to vancomycin and one $(20 \%)$ was found to be moderately susceptible. Twenty-one (77.8\%) of the 27 isolates, that were positive by microtitration plate method, were susceptible to vancomycin and six $(22.2 \%)$ were found to be moderately susceptible.

Biofilm results of phenotypic tests

Only five $(5.9 \%)$ of the $85 \mathrm{E}$. faecalis isolates produce biofilm by performing tube method. In one of the five strains, it was +3 positive; the remaining 4 isolates were found to be +2 positive. Biofilm production by tube method was not detected in any of the $E$. faecium isolate.

By performing the microtitration plate method $27(31.8 \%)$ of the $85 \mathrm{E}$. faecalis isolates produce biofilm. Biofilm production by microtitration plate method was not detected in any of the $E$. faecium isolates.

\section{Determination of the presence of esp gene region by $\mathrm{PCR}$}

As a result of the PCR process; esp gene was found in 49 of $85 \mathrm{E}$. faecalis isolates $(57.6 \%)$ and 20 of 85 E. faecium isolates $(23.5 \%)$. When phenotypic and genotypic methods were compared, the presence of esp gene was detected in 24 isolates which were positive in microtitration plate method and in five isolates which were positive in tube method. When vancomycin susceptibility and PCR results were compared; 43 of the $49 \mathrm{E}$. faecalis isolates which are esp positive, were susceptible, five of them were moderately susceptible, one of them was resistant; nine of in $20 \mathrm{E}$. faecium isolates were susceptible and 11 of them were resistant. Example gel images for $E$. faecalis are shown in Figure 1.

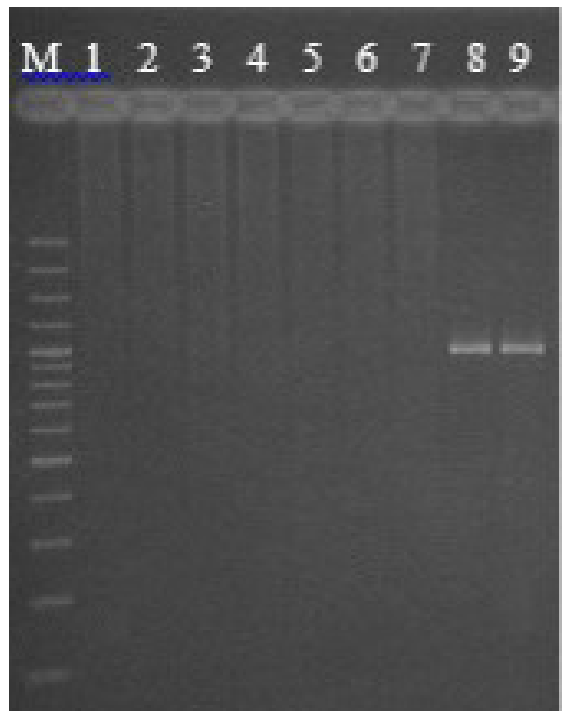

Figure 1. Agarose gel electrophoresis of $E$. faecalis M: Marker (Bioron, Germany); 1, 2, 3, 4, 5, 6 ve 7. samples were negative; 8 ve 9 . samples were positive for esp. 
The results of the analysis of disc diffusion for $E$. faecalis and $E$. faecium, tube biofilm formation, microtitration plate method and the presence of esp gene are presented in Table 2.

Table 2. Statistical analysis of $E$. faecalis and $E$. faecium species for phenotypic and genotypic methods

\begin{tabular}{|l|c|c|c|}
\hline & E. faecalis $(\mathrm{n}=85)$ & E. faecium $(\mathrm{n}=85)$ & $P$ \\
\hline Resistance to vancomycin $\mathrm{n}(\%)$ & $1(1,2)$ & 0 & $0,023^{*}$ \\
\hline Tube method $\mathrm{n}(\%)$ & $5(5,9)$ & 0 & $<0,001$ \\
\hline Microtitration plate method $\mathrm{n}(\%)$ & $27(31,8)$ & $20(23,5)$ & $<0,001$ \\
\hline Presence of esp by PCR $\mathrm{n}(\%)$ & $49(57,6)$ & 201, \\
\hline
\end{tabular}

*Fisher's excat test was used to compare.

\section{DISCUSSION and CONCLUSION}

In order to understand the ability of enterococci to cause disease, virulence characteristics and increased antibiotic resistance need to be investigated better (17). Biofilm can make microorganisms resistant to antibacterial agents and antibacterial molecules produced by the host (7).

Oli et al (18), investigated the formation of biofilm in multidrug-resistant of $E$. faecalis's obtained from clinical specimens. For this purpose, they used the plate method and tube method. In that study, it has been demonstrated from 40 isolates, 11 (27.5\%) of them were strong biofilm producer, 22 (55\%) of them were medium biofilm producer and seven (17.5\%) of them were weak biofilm or no biofilm producer. The researchers concluded that biofilm formation plays an important role in nosocomial infections.

Fallah et al (8), compared biofilm formation and antimicrobial resistance in enterococcus isolates isolated from urine samples. In the study 57 clinical isolates were included. Biofilm formation properties of isolates were investigated by phenotypically modified congo red agar method and microtitration plate method. Also with the PCR method, the presence of esp was examined. At the end of phenotypic methods, It was accepted that $26.5 \%$ of the $E$. faecalis and $75 \%$ of the $E$. faecium form biofilm. In addition, researchers found the presence of esp in 48 of the 57 enterococcal isolates. In the study, the presence of asa1 and of ebp was also investigated. As a result of the study, it was considered that biofilm formation in vitro is very complex in enterococci and the presence of esp, asa1 and of ebp genes was insufficient for biofilm formation

Dupre et al (4), have studied on virulence factors with $15 E$. faecalis and $32 E$. faecium isolates, totally 47 enterococcal isolates. In 9 of the $E$. faecalis isolate of 15,23 of the $E$. faecium isolate of 32 , esp gene were detected.

In the study of Kafil et al (19), they investigated the presence of esp in $E$. faecium and $E$. faecalis isolates, which are effective in urinary tract infection and the relationship between antibiotic resistance. 166 enterococcus strains were included in the study. It is determined that $43.3 \%$ of them are $E$. faecium, 
$56.7 \%$ of them are E. faecalis. In $76.1 \%$ of the $E$. faecium isolates and $77.9 \%$ of the $E$. faecalis isolates esp gene were found positive. In addition, it has been stated that there is a significant relationship between esp positive $E$. faecium isolates and vancomycin resistance. It has been considered that the incidence of esp in enterococci isolates, which are effective in urinary tract infection, is important in these types of infection.

Udo et al (20), have included a total number of $466 E$. faecalis isolates to their studies. These isolates were obtained from 313 urine specimens, 68 wound specimens, 36 blood specimens, 25 rectal swabs, 12 vaginal swabs and 12 other sources. It has been found that in 147 (31.5\%) of these samples esp gene was positive.

Baylan et al (15), have investigated enterococcal surface protein (esp) of a total of 91 isolates (59 $E$. faecalis, 31 E. faecium, and one $E$. gallinarum) isolated from urine cultures by molecular methods. The esp gene region was the second most common virulence factors in the study with a positivity rate of $25.6 \%$. At the end of the study, the researchers concluded that the identification of virulence factors of enterococci and the relationship of these virulence factors with antibiotics is an important research topic.

Saba Çopur et al (21), included 116 strains including 93 vancomycin-resistant enterococci (VRE) and 23 vancomycin susceptible enterococci (VSE) in their study. They have stated that $95.6 \%$ of VRE was $E$. faecium $(\mathrm{n}=89), 4.3 \%$ of the VRE was $E$. faecalis $(n=4)$, and $17.4 \%$ of VSE was $E$. faecium $(n=4)$ and $82.6 \%$ of VSE $E$. faecalis $(\mathrm{n}=19)$. PCR study revealed the presence of esp in 75 (80.6\%) of 93 VRE isolates and $16(69.9 \%)$ of 23 VSE isolates. At the end of the study, it was concluded that not only VRE but also VSE may cause important infections due to virulence factors and new studies would be useful for clarifying this issue.

Mete et al. (22) aimed to evaluate virulence factors and antibiotic susceptibility patterns of enterococcal isolates in their study. 229 enterococcal isolates were included in their study. They revealed the presence of esp in 46 (33.3\%) of the $138 \mathrm{E}$. faecalis isolates, and in $28(30.8 \%)$ of the $91 \mathrm{E}$. faecium isolates. When comparing virulence factors of vancomycin-resistant and susceptible isolates; esp gene level in vancomycin resistant $E$. faecium isolates was present as $24.1 \%$, while the esp gene was absent in vancomycinresistant $E$. faecalis isolates. In VSE isolates, the presence of esp gene was found to be $35.1 \%$ for $E$. faecalis and $29.4 \%$ for $E$. faecium. At the end of the study, the researchers emphasized that VRE can cause difficult infections to treat, especially in hospitalized patients, and that VSE can cause serious infections due to its important virulence factors.

We have studied a totally $85 \mathrm{E}$. faecalis isolates in terms of susceptibility of to vancomycin and obtained the results as follows; 70 (82.3\%) of them were susceptible, 14 (16.5\%) of them were moderately susceptible and one (1.2\%) of them was resistant. It was found that $56(65.9 \%)$ of the $85 E$. faecium isolates were susceptible and 29 (34.1\%) of them were resistant. In the isolates the biofilmproducing strains were included in the study, four of the five isolates, positive in the tube method, were found to be vancomycin susceptible and 1 of them was medium susceptible. It has been reported that 21 of the 27 isolates that were detected to produce biofilm by microtitration method, were found to be vancomycin-susceptible and six of them were moderately sensitive.

It has been reported that in esp positive $E$. faecalis strains, 43 of them were susceptible, five of them were intermediate susceptible, one of them was resistant; and in $E$. faecium isolates, nine of them were susceptible and 11 of them were resistant when compared vancomycin resistance with PCR process.

When the phenotypic methods used to detect biofilm production were compared; it has been seen that all of the five isolates, which are positive in 
tube method, were positive in the microtitration method as well. Both phenotypic methods used, it was observed that all strains with positive biofilm production were the strains of $E$. faecalis.

As a result of statistical evaluation, There is a significant difference between the resistance to vancomycin in $E$. faecalis and $E$. faecium, the presence of biofilm detected by tube and microtitration plate method, and the presence of esp detected by PCR.

As a result of PCR process; 49 (57.6\%) of the 85 E. faecalis isolates; $20(23.5 \%)$ of $85 \mathrm{E}$. faecium isolates were found to be positive in terms of the presence of esp. When phenotypic and genotypic methods were compared, the presence of esp gene was detected in 24 isolates which were positive in microtitration plate method and in 5 isolates which were positive in tube method. Based on these results, it has considered that esp gene may have a relation with biofilm formation and the only presence of esp may be insufficient in biofilm formation. New and comprehensive studies on the subject will provide important data about the mechanisms and the ability of enterococci to cause disease.

\section{ACKNOWLEDGMENTS}

This study was supported by Ondokuz Mayıs University (Project number PYO.TIP.1904.18.001).

\section{ETHICS COMITTEE APPROVAL}

* The study was approved by the Ondokuz Mayıs University Clinical Research Ethics Committee (Date: 14.09.2017 and Number: $2017 / 321$ ).

\section{CONFLICT OF INTEREST}

The authors declare no conflict of interest. 


\section{REFERENCES}

1. Tünger A, Çavușoğlu C, Korkmaz M. Asya Mikrobiyoloji. 4th ed. İzmir: Asya Tıp Kitabevi, 2005.

2. Özkaya Şahin G. Gram-pozitif kok infeksiyonları. In: Ulusoy S, ed. Gram Pozitif Kok Infeksiyonları; Sorunlar ve Çözümler. Ankara: Güneș Kitabevi, 2003:1-9.

3. Durmaz G. Enterokoklar. In: Wilke Topçu A, Söyletir G, Doğanay M, eds. Enfeksiyon Hastalıkları ve Mikrobiyolojisi. 3th ed. İstanbul: Nobel Tip Kitabevi, 2008: 2057-65.

4. Duprè I, Zanetti S, Schito AM, Fadda G, Sechi LA. Incidence of virulence determinants in clinical Enterococcus faecium and Enterococcus faecalis isolates collected in Sardinia (Italy). J Med Microbiol, 2003; 52 (6): 491-8.

5. Arıkan Akan Ö. Enterokok Türlerinin Mikrobiyolojisi ve Antimikrobiyal Direnç. In: Arman D, Ünal S, eds. Yeni ve Yeniden Gündeme Gelen İnfeksiyonlar. Ankara: Bilimsel Tıp Yayınevi, 2010: 137-49.

6. Sava IG, Heikens E, Huebner J. Pathogenesis and immunity in enterococcal infections. Clin Microbiol Infect, 2010; 16 (6): 533-40.

7. Donlan RM, Costerton JW. Biofilms: Survival mechanisms of clinically relevant microorganisms. Clin Microbiol Rev, 2002; 15 (2): 167-93.

8. Fallah F, Yousefi M, Pourmand MR, Hashemi A, Nazari Alam, Afshar D. Phenotypic and genotypic study of biofilm formation in Enterococci isolated from urinary tract infections. Microbial Pathogenesis, 2017; 108: 85-90.

9. Çetinkaya Şardan Y. Hastane Enfeksiyonları: Tanımlar, Sürveyans, Epidemilere Yaklașım. In: Wilke Topçu A, Söyletir G, Doğanay M, eds. Enfeksiyon Hastalıkları ve Mikrobiyolojisi. 3th ed. İstanbul: Nobel Tip Kitabevi, 2008: 545-57.

10. Clinical and Laboratory Standards Institute. Performance Standards for Antimicrobial Susceptibility Testing. 27th ed. CLSI supplement M100, Wayne, PA: CLSI, 2017.
11. Bektöre B. Stafilokoklar İçin Slime Testi. In: Bașustaoğlu A, Yıldıran ȘT, eds. Klinik Mikrobiyoloji Yöntemleri El Kitabı (Ceviri). 3th ed. Ankara: Atlas Yayıncılık, 2014: 13.16.3.

12. Christensen GD, Simpson WA, Younger JJ, Baddour LM, Barrett FF, Melton DM, et al. Adherence of coagulase-negative staphylococci to plastic tissue culture plates: a quantitative model for the adherence of staphylococci to medical devices. J Clin Microbiol, 1985; 22 (6): 996-1006.

13. Milletli Sezgin F, Çoban AY, Günaydın M. Investigation of biofilm formation in Acinetobacter baumannii isolates and their colistin susceptibilities in biofilm. Int J Antimicrob Agents, 2013; 41 (2): 199.

14. Us D. Serolojik Tanı Yöntemleri. Ankara: Hacettepe Üniversitesi Yayınları, 2006.

15. Baylan O, Nazik H, Bektöre B, Citil BE, Turan D, Öngen $B$, ve ark. Üriner enterokok izolatlarının antibiyotik direnci ile virülans faktörleri arasındaki ilișki. Mikrobiyol Bul, 2011; 45 (3): 430-45.

16. Shankar V, Baghdayan AS, Huycke MM, Lindahl G, Gilmore MS. Infection-derived Enterococcus faecalis strains are enriched in esp, a gene encoding a novel surface protein. Infect Immun, 1999; 67 (1): 193-200.

17. Fisher K. Phillips C. The ecology, epidemiology and virulence of Enterococcus. Microbioiogy, 2009; 155: 1749-57.

18. Oli AK, Raju S, Rajeshwari, Nagaveni S, Kelmani Chandrakanth R. Biofilm formation by multidrug resistant Enterococcus faecalis (MDEF) originated from clinical samples. J Microbiol Biotech Res, 2012; 2 (2): 284-8.

19. Kafil HS, Mobarez AM. Spread of enterococcal surface protein in antibiotic resistant Enterococcus faecium and Enterococcus faecalis isolates from urinary tract infections. Open Microbiol J, 2015; 9: 14-7. 
20. Udo EE, Al-Sweih N. Frequency of virulenceassociated genes in Enterococcus faecalis isolated in Kuwait hospitals. Med Princ Pract, 2011; 20 (3): 259-64.

21. Saba Çopur Ș, Şahin F, Göçmen JS. Determination of virulence and multidrug resistance genes with polymerase chain reaction method in vancomycinsensitive and-resistant enterococci isolated from clinical samples. Turk J Med Sci, 2016; 46 (3): 877 91.
22. Mete E, Kaleli I, Cevahir N, Demir M, Akkaya Y, Kiriș Satılmıș Ö. Enterokok türlerinin virulans faktörlerinin araștırılması. Mikrobiyol Bul, 2017; 51 (2): 101-14. 